\title{
Investigating Organizational Commitment as the Outcome of Job Satisfaction: A Study of Banking Sector of Pakistan
}

\author{
Ms. Maryam Saeed Hashmi \\ Lecturer, Institute of Business and Management, \\ University of Engineering and Technology, Lahore, Pakistan \\ E-mail: maryamhashmi57@yahoo.com
}

\author{
Dr. Imran Haider Naqvi \\ Manager Research, Development and Operations, ORIC \\ COMSATS Institute of Information Technology, Lahore, Pakistan \\ E-mail: drimranhaider@ ciitlahore.edu.pk
}

Accepted: June 27, 2012 Published: July 09, 2012

Doi:10.5296/ijld.v2i4.2077ＵRL: http://dx.doi.org/10.5296/ijld.v2i4.2077

\begin{abstract}
This study aims to elaborate the role of job satisfaction in committing employees with organization. This study tested the effect of both components of job satisfaction (intrinsic and extrinsic) on organizational commitment in banking sector of Pakistan. Data was gathered from employees working in banks of Pakistan. The study has used descriptive statistics (mean and standard deviation) to identify sample characteristics and inferential statistics (multiple linear regression) to find out the relationship between variables. Results showed the significant and positive effect of both components of job satisfaction on organizational commitment. This study is a contribution to theory and practice with an increased understanding on importance of job satisfaction in committing the employees with the organization.
\end{abstract}

Keywords: Intrinsic Job Satisfaction, Extrinsic Job Satisfaction, Organizational Commitment 


\section{Introduction}

In the current era business organizations accept the challenge of providing better-quality services to their internal customers, the employees of the organization. According to resource based view of the organization, competitive edge is attained through the human capital that is the employees of the organization (Arocas \& Camps, 2008). Organizations are recognizing the significance of employees in achieving organizational mission, goals and objectives as employees are at the frontline to face and meet the challenges faced by the organization. . The present state of affairs has "stimulated a need for employees who can take initiative, embrace risk, stimulate innovation and cope with high uncertainty" (Spreitzer, 1995). In order to achieve this, the business organizations need to have effective personnel supporting their objectives. To manage the turbulent internal and external challenges, business organizations need to focus on facets of job satisfaction as they are responsible for committing and retaining employees in a healthy workplace. A good number of the human resource practices in the organizations are humanistic in nature and are concerned with behavioral aspects of employees. Organizations need motivated, responsible and committed employees instead of those who are negligent, sluggish and disloyal. There are different factors accountable for motivated and responsible behaviors of employees and their organizational commitment. Bhatti and Nawab (2011) found role clarity, organizational climate, job satisfaction and employee empowerment as predictors of organizational commitment. Job satisfaction is found to be determinative of organizational commitment (Meyer et al., 2002) and helps in improving level of organizational commitment (John \& Saks, 2001).

\section{Need to Study Job Satisfaction as Antecedent of Organizational Commitment in Banking Sector of Pakistan}

According to Khan et al. (2011), the banking sector in Pakistan "has undergone changes for the regulation of the sector, customers' stipulation for services, industrial changes and the access of new entrants from the outside businesses". If at one hand, these reforms have overcome the problems of bureaucracy, overstaffing, high administrative costs and poor customer service, at other hand they have given a tough time to the employees as they have to meet the changes and the challenges associated with these reforms. The present conditions of banking industry of Pakistan have not only snatched the serenity of the employees but have also affected their commitment with the organization. Employee turnover is one of the major results of structural transformations in banking sector of Pakistan (Khan et al., 2011). An essential way to cope with the problem of employee retention is to understand and analyze the level of organizational commitment of the employees and the factors influencing it.

\section{Literature Review \\ 3.1 Organizational Commitment}

Organizational commitment, the spirit of the organization, is essential for the success of any organization because until or unless the employees of any organization are not loyal and sincere to it, it is difficult for organization to meet challenges and pressures faced by it from inner and outer of the organization. Research on organizational commitment covers more than 
five decades but still continues to be an area of interest. An extensive body of knowledge exists on definitions of the organizational commitment. Organizational commitment is considered both as uni dimensional (Mowday et al., 1979, Wiener, 1982) and multidimensional construct (Allen \& Meyer, 1990, O Reilly \& Chatman, 1986). Luthans (2007) defines organizational commitment as "an attitude reflecting employees' loyalty to their organization and is an ongoing process through which organizational participants express their concern for the organization and its continued success and well-being". According to Allen and Meyer (1991) multidimensional approach to organizational commitment, there are three components of organizational commitment, affective, normative and continuance. Affective commitment refers to the emotional attachment and involvement of an employee in the organization. Shaw (2003) reports affective commitment as sincere and utmost involvement of an employee with organization. Employees with high affective commitment stay with the organization because they want to. Normative commitment refers to the obligation of an employee to remain at the organization. It is based on social cognitive theory which states that a person receiving benefits is under a strong normative obligation to return it in one way or the other. Employees with high normative commitment stay with the organization because they ought to remain within the organization. Continuance commitment is calculative in nature and refers to perceived cost of leaving an employee would have to bear if he leaves the organization. They may face scarcity of alternatives, loss of seniority benefits and other negative consequences discussed above in Becker's theory of "side bets". Shaw (2003) reports that employees who stay with organization due to pension, insurance, medical benefits, long term friendships, etc exhibit a high level of continuance commitment.

\subsection{Job Satisfaction}

The growth of interest of researchers in employee behavior and its outcomes has caused them to investigate different facets of job. Job satisfaction, one of the most researched variables in industrial/organizational psychology is one of the major factors that influence an employee experience at workplace. Job satisfaction can be defined in terms of an employee's physical and emotional feeling (Hoppock, 1935). Luthans (2007) defined job satisfaction as "a pleasurable or positive emotional state resulting from the appraisal of one's job or job experience. Herzberg two factor theory emphasizes intrinsic and extrinsic job satisfaction notion. Following this theory Pritchard and Peters (1974) established that intrinsic rewards (sense of achievement, feeling of doing an significant job etc.) are responsible for intrinsic job satisfaction and extrinsic rewards (pay, promotion, job security etc.) are responsible for extrinsic job satisfaction of employees. Moreover, this study also stated that intrinsic rewards are given to an employee by him/herself while extrinsic rewards are given by the organization. Intrinsic job satisfaction is about how an employee feels about his or her job while extrinsic job satisfaction is about how an employee feels about the aspects of his or her work that are external to the work itself (Spector, 1997). Nasurdin and Ramayah (2003), refers to the study conducted by O'Reilly and Caldwell (1980), states that intrinsic rewards such as challenging work, variety and opportunity to use one's own skills and extrinsic rewards such as pay, promotion, supervision and working conditions contribute to job satisfaction. Researchers and 
practitioners have focused on job satisfaction because they believe that it influences employees' job performance and commitment to the organization.

\subsection{Relationship between Job Satisfaction and Organizational Commitment}

Job satisfaction is a variable that has a close association with employee organizational commitment in literature and it is intuitively believed that satisfied employees are loyal to their organization. Job satisfaction and employee organizational commitment have been widely researched in the literature of organizational behavior (Freund, 2005; Parenall, 2003). John and Saks (2001) stated that job satisfaction leads to organizational commitment and according to Meyer et al. (2002) job satisfaction determines organizational commitment. Parenall (2003) found the partial relationship between these two variables while William and Hacks (1986) found a strong positive relationship between job satisfaction and organizational commitment. Other studies (Yousef, 2001; Chen, 2007; Allen et al., 2003) have also investigated the relationship between job satisfaction and employee's organizational commitment but mixed results were found. Job satisfaction positively effects affective and normative commitment but not continuance commitment (Meyer \& Allen, 1997; Celik, n.d.). According to Jha (2010) "The organization which is recognizing individual effort and is rewarding them may generate pool of people who perceive high degree of obligation and feeling that this organization at least is recognizing the effort".

\section{Research Problem}

Literature confirms a significant relationship of job satisfaction with organizational commitment. As this study selected the banking sector of Pakistan, during the preliminary investigation it collected facts that turnover in banking sector has been at its peak during the recent decade. Low organization commitment among bankers of all cadres was reported as a complaint that all banks were facing. As literature indicates that job satisfaction plays a significant role in persuading an employee to acquire good degree of organizational commitment, the study developed interest in exploring does job satisfaction commit bankers in Pakistan. If yes, how much?

Based upon literature review, this study develops the following hypothesis:

H1: Intrinsic job satisfaction positively and significantly predicts organizational commitment. H2: Extrinsic job satisfaction positively and significantly predicts organizational commitment.

\section{Research Methodology}

This research is a non contrived study conducted in field and studies the relationship between job satisfaction and organizational commitment in banks of Pakistan (Lahore, Sargodha, Karachi and Islamabad). Unit of analysis of this study are employees working in banking sector of Pakistan. The study is cross sectional as the data is collected in one point in time from individual to describe the relationship between the variables at that particular time. Sample size for this study is 384 and sample was selected through simple random sampling. The study has used survey approach for data collection. Response rate was $80.7 \%$ as 310 out of 384 
questionnaires were retrieved. To measure the job satisfaction of the employees, Minnesota Satisfaction Questionnaire short form developed by (Weiss et al., 1967) are adopted in this study and to measure organizational commitment, this study uses Meyer and Allen (1991) scale. Validity and reliability was tested before analyzing the data for relationship between variables. The value of Cronbach alpha was 0.852 . The study used exploratory factor analysis to test validity of instrument. The study found that factor loading for all dimensions of variables after extraction was above 0.7 which ensures the validity of the instrument. The study has used 7 point Likert Scale from strongly agree to strongly disagree to measure responses.

\section{Data Analyses and Results}

The study has used SPSS version 17 for data analyses. The study has used descriptive statistics to measure characteristics of sample. To find out the relationship between variables, the study has used step wise regression. Descriptive statistics for sample showed that majority of respondents were from gender male ( $\mathrm{n}=194$, that is $62.6 \%$ ), belonged to age group of 36-45 ( $\mathrm{n}$ $=94$, that is $30.3 \%)$, had qualification of Master Degree $(n=177$, that is $57.1 \%)$, were having job tenure of 10 or more years $(n=151$, that is $48.7 \%)$ and belonged to middle management position $(n=161$, that is $51.9 \%$ ). Descriptive statistics for job satisfaction (mean= 5.12, S.D = 1.045) showed an above average score. The score of employees on both components of job satisfaction i.e. intrinsic $($ mean $=5.36, \mathrm{~S} . \mathrm{D}=1.097)$ and extrinsic $($ mean $=4.97, \mathrm{~S} . \mathrm{D}=1.033)$ was above average. The results with respect to components of job satisfaction indicated that employees were experiencing both intrinsic and extrinsic job satisfaction at their workplace. Descriptive statistics for organizational commitment have shown that employees score on organizational commitment was above average (mean= 4.21, S.D $=0.700$ ). The results with respect to components of organizational commitment showed that employees score were highest for affective commitment (mean= 5.18, S.D = 1.124) followed by the score on normative commitment (mean $=5.01$, S.D $=01.093$ ) however, employees scored least on continuance commitment (mean=4.14, S.D =1.045). The results of multiple linear regression are given below:

Table 1.1

Model Summary

\begin{tabular}{|l|l|l|l|}
\hline $\mathrm{R}$ & $\mathrm{R}^{2}$ & Adjusted $\mathrm{R}^{2}$ & Standard Error of Estimate \\
\hline $.881^{\mathrm{b}}$ & .777 & .776 & .446 \\
\hline
\end{tabular}

Table 1.2

ANOVA

\begin{tabular}{|c|l|l|l|l|l|}
\hline Model & $\begin{array}{l}\text { Sum } \\
\text { Squares }\end{array}$ & Df & Mean Square & F & Sig. \\
\hline Regression & 212.869 & 2 & 106.434 & 534.966 & $.000^{\mathrm{b}}$ \\
Residual & 61.079 & 308 & .199 & & \\
Total & 273.948 & 310 & & & \\
\hline
\end{tabular}


Table 1.3

Coefficients $^{\mathbf{a}}$

\begin{tabular}{|c|c|c|c|c|c|c|}
\hline \multirow[t]{2}{*}{ Model } & & \multicolumn{2}{|c|}{$\begin{array}{l}\text { Unstandardized } \\
\text { Coefficients }\end{array}$} & \multirow{2}{*}{$\begin{array}{l}\text { Standardized } \\
\text { Coefficients } \\
\text { Beta }\end{array}$} & \multirow[b]{2}{*}{$\mathrm{t}$} & \multirow[b]{2}{*}{ Sig. } \\
\hline & & B & Std. Error & & & \\
\hline (Constant) & & .563 & .145 & & 3.891 & .000 \\
\hline $\begin{array}{l}\text { Intrinsic } \\
\text { satisfaction }\end{array}$ & Job & .521 & .032 & .564 & 16.388 & .000 \\
\hline $\begin{array}{l}\text { Extrinsic } \\
\text { satisfaction }\end{array}$ & Job & .380 & .032 & .412 & 11.964 & .000 \\
\hline
\end{tabular}

a. Dependent Variable: OC

Table 1.1 indicates that both components of job satisfaction collectively explain $77 \%$ of variance in organizational commitment. Table 1.2 is indicating that $F$ value is highly significant (Sig.= 0.00) which ensures validity of overall model. Table 1.3 indicates that the unstandardized regression coefficients (B) for predicting organizational commitment from components of job satisfaction. The highest unstandardized coefficient for predicting organizational commitment in intrinsic job satisfaction $(\beta=0.521)$ followed by extrinsic job satisfaction $(\beta=0.380)$. The standard errors of the estimates are less 1 which means that this study is confident about its results. . Table 1.3 is also indicating the relative importance of each component of job satisfaction in predicting organizational commitment by its respective $t$ value. It is well evident that importance of intrinsic job satisfaction $(t=16.38, p=0.00)$ in predicting organizational commitment is higher than extrinsic job satisfaction $(\mathrm{t}=11.964, \mathrm{p}=0.00)$. it is well evident from the results of the study that both intrinsic and extrinsic job satisfaction significantly and positively affect organizational commitment. Therefore, the study substantiates both hypotheses.

\section{Discussion}

Bankers in Pakistan showed a slightly above average response on organizational commitment and above average response on job satisfaction. However, the regression analyses indicated that both components of job satisfaction (intrinsic and extrinsic) significantly and positively influence level of commitment for employee working in banks of Pakistan. The current study finds that there is direct and highly significant relationship between job satisfaction and organizational commitment $\left(\mathrm{R}=0.881, \mathrm{p}_{\mathrm{n}} 0.00\right)$. This study finds that job satisfaction significantly affects organizational commitment employees working in banking sector of Pakistan. The results of this study with respect to relationship between job satisfaction and organizational commitment are consistent with other various researchers (Cote and Heslin, 2003 and Zafar and Chughtai, 2006 Azeem, 2010). Based upon the findings related to relationship between job satisfaction and organizational commitment, this study makes some conclusions. First, employees who feel that their effort for organization is recognized, they have autonomy to use their judgment and they have chance to make use of their abilities, they are intrinsically satisfied with their job. When employees feel intrinsic job satisfaction, their level of organizational commitment is enhanced. Second, when employees feel that their 
relationship with supervisor and peer is good, their working conditions are pleasant, they are provide with promotion opportunities and salary raise etc., they are extrinsically satisfied with job. When employees feel extrinsic job satisfaction, their level of organizational commitment is enhanced.

\section{Conclusion}

The current study has identified an essential role of job satisfaction in committing employees with organization. Findings of this study are helpful for organizations that can be instrumental in satisfying the employees with their job and arousing feelings of commitment with organization. Organizational commitment is strength of any organization. Job satisfaction plays a significant role in committing employees with organization. Perception of meaningful tasks, autonomy in work, feeling of skillfulness in performing tasks, perception of impacting work outcomes in employees and feeling of intrinsic and extrinsic job satisfaction lead to high level of commitment of employees with organization. It is a common phenomenon from the ages back that if you have to get something, you have to invest something. Therefore, organizations must provide such working environment in which employees feel satisfied with their job which will ultimately lead to high level of organizational commitment, improved employee and organizational performance.

\section{Recommendations}

Based upon results, this study makes some recommendations for managers. Organizational commitment can be instilled in the employees by providing them with desirable corporate culture which not only motivates them to work properly but also arouses the feelings of loyalty in them with the organization. Managers can improve employees organizational commitment by introducing performance based bonuses and can plan attractive wages for current, newly hired and to be hired employees. Rewards motivate employees to perform well because when employees feel that their efforts are recognized at organizational level and they are rewarded for their satisfaction level increases.

\section{Limitations of the Study}

This was a cross sectional study and the results of this study were limited to the time frame in which data was gathered. Future researchers can analyze the relationship between variables by conducting longitudinal study. Data of the study was collected only from Lahore, Sargodha and Karachi. The study includes only those predictors of organizational commitment which are in scope of this study. Future researchers can include the other predictors of organizational commitment which this study has not taken into consideration.

\section{References}

Allen, N.J., \& Meyer, J.P. (1990). The measurement and antecedents of affective, continuance and normative commitment to the organizations. Journal of Occupational Psychology, $63,1-18$. 
Allen, N.J., \& Meyer, J.P. (1991). A three-component conceptualization of organizational commitment. Human Resource Management Review, 1, 61-98.

Arocas, R, L., \& Camps, J. (2008). A model of high performance work practices and turnover intention. PersonnelReview, 1, 26-46.

Chen, Y.J. (2007). Relationships among service orientation, job satisfaction, and organizational commitment in the international tourist hotel industry. Journal of American Academy of Business, 11, 71-82.

Freund, A. (2005). Commitment and job satisfaction as predictors of turnover intentions among welfare workers. Administration in Social Work, 29, 5-17.

Hoppock, R. (1935). Job satisfaction. New York: Harper.

Jha, S. (2010). Influence of psychological empowerment on affective, normative and continuance commitment: A study in Indian it industry. International Journal of Organizational Behavior, 15 (1), 53-72.

Johns, R. (2005). Determinants of organizational commitment among U.S. workers. Unpublishedmaster's thesis, Duquesne University.

Khattak, J., Khan, M., Haw, A., Arif, M., Minhas, A. (2011). Occupational stress and burnout in Pakistan's banking sector. African Journal of Biotechnology,5(3), 810-817.

Khan, M. A., Kashif Ur, R., Ijaz Ur, R., Safwan, N., \& Ahmad, A. (2011). Modeling link between internal service quality in human resources management and employees retention: A case of Pakistani privatized and public sector banks. African Journal of Business Management, 5(3), 949-959.

Meyer, J. P., Stanley, D. J., Herscovitch, L. \& Topolnytsky, L. (2002). Affective, continuance, and normative commitment to the organization: A meta-analysis of antecedents, correlates, and consequences. Journal of Vocational Behavior, 61, 20-52.

Meyer, J.P. (1997). Organizational commitment. International Review of Industrial and Organizational Psychology, 12, 175-228.

Mowday, R. T., Steers, R. M., \& Porter L. W. (1979). The measurement of organizational commitment. Journal of Vocational Behavior, 14,224-227. 
Nasurdin, A.M., \& Ramayah, T. (2003). The link between satisfaction and commitment: is it different for old and young workers? The National Human Resource Development Conference Proceedings, $15^{\text {th }}-16^{\text {th }}$ December 2003, Kuching, Malaysia.

O Reilly, C., \& Chatmen, J. (1986). Organizational commitment and psychological attachment: The effects of compliance, identification and internalization on pro social behavior. Journal of Applied Psychology, 71, 429499.

Spector, P.E. (1997). Job satisfaction: Application, assessment, causes and consequences. Thousand Oaks, CA: Sage.

Shaw, J. D., Delery, J. E., \& Abdulla, M. H. A., (2003). Organizational commitment and performance among guest workers and citizens of an Arab country. Journal of Business Research, 56, 1021-1030.

Spreitzer, G. M. (1995). Psychological empowerment in the workplace: Dimensions, measurement, and Validation. .Academy of Management Journal, 38(5), 1442-1465.

Parenall, J.A. (2003). Propensity of participative decision making, job satisfaction, organizational commitment, organizational citizenship behavior and intentions to leave. The Multinational Business Review, 11(1), 45-65.

Pritchard, R. D. Peters , L. H. (1974). Job duties and job interest as predictors of intrinsic and extrinsic satisfaction. Organizational Behavior and Human Performance.

Wiener, Y. (1982). Commitment in organizations: A normative view. Academy of ManagementReview. 7(3), 418-428.

Yousef, D.A. (2001). Islamic work ethic: a moderator between organizational commitment and job satisfaction in a cross cultural context. Personnel Review, 30, 152-69. 